\title{
Pengaruh Motivasi Pengurus DKM Mesjid dan Kepemimpinan Ketua DKM \\ Mesjid terhadap Kompetensi Manajerial Ketua DKM Mesjid \\ di Kota Bogor
}

\author{
M. Taufik Hidayatulloh \\ Fidkom UIN Syarif Hidayatullah Jakarta
}

taufikmtht@yahoo.co.id

\begin{abstract}
ABSTRAK
Penelitian ini membahas tentang pengaruh motivasi pengurus DKM mesjid dan kepemimpinan ketua DKM mesjid terhadap kompetensi manajerial ketua DKM mesjid. Penelitian dilakukan dari bulan Mei-November 2015 di Kota Bogor, Provinsi Jawa Barat. Pengurus DKM mesjid jami merupakan populasi yang diamati pada penelitian ini yang berjumlah 456 orang. Sampel ditetapkan tiap kecamatan dengan menggunakan teknik proportionate stratified random sampling yang berjumlah 215 orang. Data dikumpulkan dengan menggunakan kuesioner, observasi, wawancara semi terstruktur dan studi dokumentasi. Analisis statistik menggunakan analisis regresi linier berganda. Hasilnya menunjukkan bahwa motivasi pengurus DKM mesjid berada pada kategori sedang dengan dorongan berafiliasi menempati skor lebih tinggi dibandingkan dengan subpeubah motivasi lainnya, kepemimpinan ketua DKM mesjid berada pada kategori sedang dengan skor tertinggi ada pada kemampuan berhubungan dengan orang lain dan skor terendah ada pada kemampuan teknis, kompetensi manajerial ketua DKM mesjid menurut penilaian responden secara umum berada pada kategori sedang dengan kompetensi kerjasama internal dinilai paling tinggi. Hasil analisis regresi linier bergdana menunjukkan bahwa motivasi pengurus DKM mesjid dan kepemimpinanan ketua DKM mesjid memberikan pengaruh nyata positif terhadap kompetensi manajerial ketua DKM mesjid.
\end{abstract}

(Kata kunci : motivasi, kepemimpinan, kompetensi manajerial)

\begin{abstract}
This article focused on explanation influence of motivation of mosques DKM Carateker dan leadership of head of mosque's DKM on managerial competency of leader of mosque's DKM. The research was conducted in May-November 2015 located in Bogor City, West Java Province. The population was 456 mosques DKM Carateker. Meanwhile the respondents amounted of 215 of mosque's DKM caretaker. Sampling process was done by proportionate stratified rdanom sampling procedure. The Data collection techniques were questionnaire, observation, in-depth interview, dan documentary study. The statistical analysis used was regression analysis. The findings indicated that the working motivation showed in medium to high level. It shows by
\end{abstract}


highest score in the needs or motif to be affiliated. The leadership of DKM's leader stated in medium to high category with highest score is the ability to get connected to other or to socialize dan making connection. The managerial competency also stated in medium to high category, specially internal cooperation competency. Regression analysis shows that motivation of mosques DKM Carateker dan leadership of DKM's leader influenced managerial competency of leader of mosque's DKM.

Key words: motivation, leadership, managerial competency

\section{PENDAHULUAN}

\section{Latar Belakang}

Setiap Muslim memiliki tugas untuk syiar Islam. Salah satu syiar tersebut adalah memakmurkan mesjid. Allah SWT mengabarkan tentang karakteristik dan keutamaan pemakmur mesjid sebagaimana firman-Nya "Hanyalah yang memakmurkan masjidmasjid Allah ialah orang-orang yang beriman kepada Allah dan hari kemudian, serta tetap mendirikan shalat, menunaikan zakat dan tidak takut (kepada siapapun) selain kepada Allah, maka merekalah orang-orang yang diharapkan termasuk golongan orang-orang yang mendapat petunjuk.” (QS. At Taubah (9) : 18). Betapa pentingnya posisi mesjid sehingga diposisikan sebagai rumah yang menenangkan dan tempat yang dicinta. Beberapa hadits menyebutkan ; "Tempat yang paling dicintai Allah adalah masjid-masjid, dan tempat yang paling dibenci Allah adalah pasar-pasar." (HR. Muslim). Beliau juga telah bersabda, "Masjid adalah rumah setiap orang yang beriman." (HR. Abu Nu'aim dan dihasankan oleh al-Albani). Dalam sabda yang lainnya disebutkan, "Tidaklah seseorang berdiam diri di dalam masjid untuk shalat dan dzikir kecuali Allah akan menyambutnya dengan senang, sebagaimana orang- orang yang kehilangan menyambut saudaranya yang hilang apabila dia kembali kepada mereka.” (HR Ibnu Majah dan dishahihkan oleh al-Albani).

Mesjid sebagai tempat utama dan memiliki fungsi penting dalam pembinaan ummat telah tercatat dalam sejarah melalui keberfungsian mesjid di era Rasulullah hingga zaman kemajuan peradaban Islam. Sebagaimana diwakili oleh fungsi Masjid Nabawi yang mesti diteladani secara kontekstual oleh setiap Muslim, pengurus masjid, pemerintah dan para pemimpin umat. Kesepuluh fungsi Masjid Nabawi adalah ; tempat ibadah, konsultasi dan komunikasi masalah sosial, ekonomi, dan budaya, pendidikan, 
santunan sosial, latihan dan persiapan peralatan militer, pengobatan korban perang, perdamaian dan pengadilan sengketa, menerima tamu, menawan tahanan dan sebagai pusat penerangan atau pembelaan agama (Shihab 1999 : 462).

Pada zaman kemajuan peradaban Islam, mesjid menjadi tempat bagi berkumpulnya kalangan akademisi dan para ahli untuk mengkaji berbagai macam ilmu sebagai suatu tradisi. Namun demikian, kini masjid tidak lagi menjadi pusat kajian. Umat Islam lupa untuk mengembangkan tradisi keilmuan Islam yang pernah gemilang. Masjid menjadi sepi dari tradisi pengkajian khasanah keilmuan kecuali hanya untuk kajian fiqih atau digunakan sebagai tempat untuk menggelar dzikir. Masjid hanya merupakan sebuah tempat yang sesekali dikunjungi, tidak diberdayakan, dikelola dai diarahkan pada hal-hal yarg bersifat keumatan (Rifa'i dan Fakhruroji 2005 : 39-40).

Dengan demikian, permasalahan kemesjidan di zaman modern ini berkisar pada peran sosial mesjid yang sedemikian lemah di tengah-tengah krisis moral umat. Rukmana (2009 : 18) dalam hal ini mengatakan bahwa peran sosial mesjid mendapatkan tantangannya di zaman modern ini di tengah krisis moral budaya masyarakat Muslim. Salah satu aktor kunci tentulah para pengurus dan terutama pemimpin DKM mesjid. Diperlukan suatu kemampuan mengelola mesjid dari para pengurusnya, khususnya pemimpin DKM mesjid dalam mengelola mesjid menuju mesjid yang makmur dan dirindukan ummat. Selain membutuhkan peran kepemimpinan juga dukungan dari pengurus mesjid yang termotivasi. Penelitian ini dimaksudkan untuk menganalisis beberapa peubah yang efektif berpengaruh terhadap kompetensi manajerial ketua DKM mesjid.

Dari paparan di atas yang menjadi permasalahan dalam tulisan ini adalah Bagaimana motivasi pengurus DKM mesjid, kepemimpinan ketua DKM mesjid dan kompetensi manajerial ketua DKM mesjid ? Apakah motivasi pengurus DKM mesjid dan kepemimpinan ketua DKM mesjid mempengaruhi kompetensi manajerial ketua DKM mesjid ? Tujuan yang hendak dicapai dari tulisan ini adalah untuk mendapatkan gambaran bagaimana motivasi pengurus DKM mesjid, kepemimpinan ketua DKM mesjid dan kompetensi manajerial ketua DKM mesjid. Berikutnya menganalisis pengaruh motivasi pengurus DKM mesjid dan kepemimpinan ketua DKM mesjid terhadap kompetensi manajerial ketua DKM mesjid.

\section{Motivasi}

Istilah motivasi memiliki pengertian yang beragam. Namun demikian, motivasi ini merupakan unsur penting dalam diri manusia karena berhubungan secara langsung 
dengan aktivitas manusia pada umumnya seperti bekerja. Beberapa definisi motivasi diberikan oleh berbagai pakar. Salah satunya adalah menurut Phares dan Chaplin (1997, diacu dalam Shah dan Gardner 2008) yang menyatakan bahwa motivasi adalah "Kekuatan yang mempengaruhi dan sekaligus mengarahkan pencapaian tujuan tertentu daripada tujuan yang lain". Vroom (diacu dalam Timpe 1986) menyebutkan motivasi sebagai sebuah proses mengelola pilihan yang dibuat oleh seseorang di antara berbagai alternatif dari aktivitas yang mungkin diambil. Schiffman dan Kanuk (1992) mendefinisikan motivasi sebagai daya gerak dalam diri individu yang mendorongnya untuk melakukan tindakan yang disebabkan oleh adanya tegangan yang diakibatkan oleh belum terpenuhinya suatu kebutuhan. Kontz et al. (1980) berpendapat bahwa motivasi merupakan dorongan dan usaha untuk memenuhi dan memuaskan suatu kebutuhan atau mencapai suatu tujuan. Terry (1997) menjelaskan bahwa motivasi adalah keinginan yang terdapat pada seseorang individu untuk melakukan tindakan-tindakan.

Motivasi itu sendiri terdiri dari dua macam, yaitu motivasi intrinsik dan motivasi ekstrinsik. Motivasi intrinsik adalah dorongan yang berasal dari dalam diri seseorang untuk melakukan sesuatu, selanjutnya adalah motivasi ekstrinsik sebagai dorongan dari luar diri seseorang sehingga melakukan sesuatu hal (Reece dan Brdant 1981). McClelldan (diacu dalam Shah dan Gardner 2008) mengemukakan tiga macam kebutuhan sebagai berikut : Need for Achievement-yaitu kebutuhan untuk berprestasi, Need for Affiliation-yaitu kebutuhan untuk berhubungan sosial, dan Need to Poweryaitu kebutuhan untuk berkuasa. Ada kesamaan dengan motivasi dari Alderfer (diacu dalam Sunyoto 2013 :3) yang mengemukakan teori ERG (existence, relatedness dan growth).

Beberapa indikator untuk mengukur motivasi adalah; durasi kegiatan, frekwensi kegiatan, persistensinya ketetapan dan kelekatannya pada tujuan kegiatan, ketabahan, keuletan dan kemampuan dalam menghadapi rintangan dan kesulitan untuk mencapai tujuan, devosi pengabdian dan pengorbanan berbagai hal untuk mencapai tujuan, tingkatan aspirasinya, tingkatan kualifikasi prestasi atau produk atau output yang dicapai, arah sikapnya terhadap sasaran kegiatan (Muliadi 2015 : 53).

\section{Kepemimpinan Ketua DKM Mesjid}

Pemimpin merupakan sumber daya manusia kunci dalam organisasi apapun (Komaruddin 1994 : 229). Kepemimpinan merupakan kemampuan untuk memakai pengaruh dalam lingkungan atau situasi organisasi (Ivansevich dan Matteson 2008). Selanjutnya, kepemimpinan diartikan sebagai usaha untuk mempengaruhi orang lain 
secara perorangan melalui proses komunikasi untuk mencapai sesuatu atau beberapa tujuan (Munir 2012 : 183). Yukl (2015 : 9) mendefinisikan kepemimpinan sebagai proses mempengaruhi orang lain untuk memahami dan menyetujui apa yang dibutuhkan dalam melaksanakan tugas dan bagaimana melakukan tugas itu serta proses untuk memfasilitasi upaya individu dan kolektif guna mencapai tujuan bersama. Kepemimpinan yang efektif mampu mengkomunikasikan nilai-nilai organisasi kepada anggota organisasi untuk menerjemahkan visi dan misi dalam aktifitas sehari-hari (Summers 2009 : 135; Buhler $2007: 328$ ).

Menurut Robbin (1996) terdapat tiga pendekatan teori kepemimpinan, yaitu : pendekatan teori sifat, pendekatan teori perilaku, dan pendekatan teori kontinjensi atau situasional. Robert Katz (dalam Suryadi 2009 : 73-74, Yukl 2015 : 218) menyebutkan indikator pengukuran kepemimpinan meliputi: human relation skill, technical skill dan conceptual skill. Seorang pemimpin yang melakukan breakthrough berarti ia memecahkan kesunyian, melawan mitos dan berhadapan dengan kesulitan (Kasali 2008 : 166). Salah satu indikator umum kefektifan pemimpin adalah hingga sejauh mana kinerja tim atau unit organisasi itu meningkat daan sejauh mana pencapaian tujuan difasilitasi, sikap dan persepsi pengikut terhadap pemimpin, kontribusi pemimpin pada mutu proses group yangdirasakan oleh para pengikut atau pengamat dari luar dan karir yang yang sukses sebagai pemimpin (Yukl 2015 : 11).

Terkait dengan efektifitas pemimpin akan menyebabkan tercapai tidaknnya tujuan sesuai rencana yang telah ditetapkan. Berdasarkan telaah pustaka, ada enam hal seorang manajer dapat dikatakan sebagai pemimpin yang efektif bila mampu ; menentukan strategi yang tepat, menjadi perencana yang tangguh, menjadi organisator yang cekatan, motivator yang efektif, pengawas yang objektif dan rasional serta penilai yang tak terpengaruh oleh pertimbangan yang subjektif atau emosional (Uha 2015 : 154).

\section{Kompetensi Manajerial Ketua DKM}

Kompetensi merupakan karakteristik yang menetap (kemampuan, keahlian) dari seseorang yang berdampak pada kinerjanya (Spencer dan Spencer 1993; Stone dan Bieber 1997; Cooper dan Graham 2001; Culp et al. 2007; Wibowo 2014 : 272). Adapun Wisher (diacu dalam Kurniawan dan Jahi 2005) menyatakan bahwa kompetensi merupakan kombinasi antara ; pengetahuan, keterampilan dan kemampuan. Klausmeier dan Goodwin (1971) Lucia dan Lepsinger (1999, diacu dalam Marius dkk. 2007) menyebutkan bahwa kompetensi merupakan kombinasi dari pengetahuan, keterampilan 
dan sikap. Stone dan Beiber (1997) menyatakan bahwa kompetensi merupakan aplikasi dari pengetahuan, keterampilan teknik dan karakteristik personal yang diarahkan pada upaya memahami kinerja. Sementara itu model kompetensi tersebut dibuat di sekitar keterampilan individual dan kebutuhan kelompok untuk masa depan selain digunakan sebagai pembuatan keputusan.

Terkait dengan kompetensi seseorang menurut Spencer dan Spencer (1993) memiliki lima tipe, yaitu : Motives, yaitu menyangkut konsistensi pikiran atau keinginan yang menyebabkan perbuatan; Traits, yaitu suatu karakteristik yang bersifat fisik dan respon yang baik serta konsisten terhadap situasi atau informasi yang ada; Self concept, yaitu sikap dan nilai-nilai yang dimiliki seseorang. Sikap dan nilai diukur melalui tes kepada responden untuk mengetahui nilai yang dimiliki seseorang dan apa yang menarik bagi seseorang untuk melakukan sesuatu; Knowledge, yaitu mengenai informasi yang dimiliki seseorang dalam bidang tertentu dan Skill, yaitu kemampuan untuk melaksanakan suatu tugas tertentu baik secara fisik maupun mental. Dari ke lima karakteristik kompetensi tersebut, pengetahuan (knowledge) dan keterampilan (skill) sifatnya dapat dilihat (visible) dan mudah dikembangkan. Sedangkan konsep diri (self concept), watak (traits) dan motif (motives) sifatnya tidak tampak (hidden) dan lebih sulit untuk dikembangkan.

Brewerton (2004, diacu dalam Rutherford 2004) menjelaskan orang tidak hanya menggunakan satu buah kompetensi dalam satu kurun waktu, mereka menggunakan beragam kompetensi secara serempak yang merupakan kombinasi antara kompetensi khusus dan kompetensi kunci. Menurutnya, kompetensi terbagi menjadi dua kelompok besar, yaitu Specific competencies dan Key competencies. Specific competencies, merupakan sebuah kompetensi khusus yang melingkupi konteks terbatas pada satu bidang pekerjaan seseorang dan Key competencies, merupakan kompetensi yang dibutuhkan oleh setiap orang dalam mengarungi kehidupannya dalam konteks yang luas.

Kompetensi berdasarkan cakupan kerja terdiri atas kompetensi personal, publik dan profesional (Cooper dan Graham 2001). Hidayatulloh (2014) merumuskan jenis kompetensi sebagai personal, profesional dan manajerial. Untuk mengukur peubah ini digunakan beberapa indikator seperti kompetensi kerjasama internal, kompetensi mengelola organisasi DKM mesjid, dan kompetensi menggalang kerjasama kelembagaan. Dengan demikian, konsep dasar kompetensi manajerial ketua DKM mesjid yang digunakan pada penelitian ini merupakan sebuah kemampuan individu ketua DKM mesjid yang terdiri dari pengetahuan, keterampilan, sikap, motivasi, 
kekosmopolitan, pendidikan, bidang keahlian dan pengalaman yang dipersiapkan untuk menghadapi pekerjaannya sebagai ketua DKM mesjid secara efektif.

\section{METODE PENELITIAN}

Penelitian ini menggunakan rancangan Ex post facto untuk mengetahui motivasi pengurus DKM mesjid dan kepemimpinan ketua DKM mesjid serta hubungannya dengan kompetensi manajerial ketua DKM mesjid. Penelitian ini dilakukan di Kota Bogor, Provinsi Jawa Barat pada Mei sampai November 2015. Dari seluruh 456 orang pengurus DKM mesjid jami yang menjadi populasi, sampel penelitian hanya sejumlah 215 orang yang ditetapkan berdasarkan teknik proportionate stratified randnom sampling.

Penelitian ini memerlukan berbagai data untuk diolah dan dianalisis. Data yang diperlukan merupakan data yang bersifat factual, terukur maupun data yang bersifat penilaian responden terhadap kondisinya, kemudian dikelompokkan dalam skala interval berdasarkan kuartil atau pertimbangan tertentu lainnya. Pengelompokan ini dilakukan untuk menyederhanakan data yang sangat beragam sehingga mudah untuk diinterpretasikan. Untuk mendapatkan berbagai data yang diperlukan maka dibuatlah instrumen penelitian berupa kuesioner yang berisikan butir-butir pertanyaan dengan susunan pertanyaannya didasarkan pada peubah hasil kajian teoritik yang kemudian dijabarkan kepada kisi-kisi penyusunan instrumen yang menjabarkan jenis peubah, definisi operasional dan indikator pengukuran. Pertanyaan yang diajukan terdiri atas pertanyaan tertutup dan pertanyaan terbuka. Pertanyaan tertutup disajikan dengan cara menyediakan pilihan jawaban tertentu, sedangkan pertanyaan terbuka disajikan dengan cara memberikan kesempatan kepada responden memberikan alternatif jawabannya.

Analisis kualitatif dilakukan dengan menggunakan pendekatan induktif, yaitu dari hasil wawancara semi terstruktur dan hasil pengamatan di lapangan. Sebaran kategori peubah yang diteliti dianalisis dengan menggunakan analisis statistik deskriptif. Analisis kuantitatif untuk melihat pengaruh peubah bebas terhadap peubah terikat dilakukan dengan menggunakan regresi linier bergdana.

\section{HASIL DAN PEMBAHASAN}

\section{Deskripsi Peubah Penelitian}

Motivasi pengurus DKM mesjid berada pada kategori sedang (skor mencapai 75.7). Baik pada peubah maupun subpeubahnya, ketua DKM mesjid selalu memberikan 
penilaian lebih tinggi dibandingkan dengan anggota DKM mesjid. Dari seluruh subpeubah motivasi, dorongan berafiliasi menempati skor lebih tinggi dibandingkan dengan subpeubah lainnya. Penilaian ini dikontribusi oleh ketua DKM mesjid yang menilai tinggi terkait dorongan berafiliasi ini. Hal ini bisa dibaca bahwa ketua DKM mesjid melihat dorongan untuk berinteraksi atau bersilaturahim dengan beragam pihak menjadi motivasi utama dari para pengurus DKM mesjid. Namun sedikit berbeda dengan penilaian anggota DKM mesjid yang menilai dorongan pengaruh pengurus lebih dominan dibandingkan dengan peubah maupun subpeubah lainnya.

Dorongan berprestasi responden yang menonjol terlihat adalah berkaitan dengan adanya kesempatan untuk mengaplikasikan cara-cara baru dalam menyelesaikan pekerjaan sebagai pengurus mesjid. Sifat jabatan sebagai pengurus mesjid yang sukarela telah memungkinkan responden secara lebih leluasa mengutarakan gagasan dan memperlihatkan penerapan cara-cara baru dalam menyelesaikan persoalan pelayanan kejamaahan. Hal lainnya yang terlihat dengan dorongan berprestasi adalah adanya kesenangan dan kebahagiaan atas amanah jabatan di kepengurusan DKM mesjid.

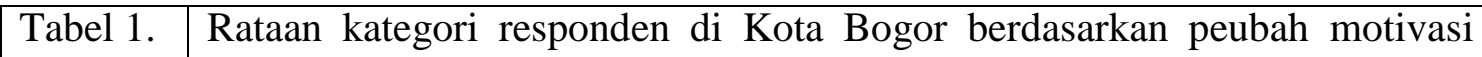
pengurus DKM mesjid (Tahun 2015)

\begin{tabular}{|c|c|c|c|c|}
\hline \multirow{2}{*}{$\begin{array}{c}\text { Motivasi pengurus DKM } \\
\text { mesjid }\end{array}$} & Pengukuran & \multicolumn{2}{|c|}{ Rataan } & Total \\
\cline { 3 - 4 } & & Ketua DKM & $\begin{array}{c}\text { Anggota } \\
\text { DKM }\end{array}$ & \\
\hline Dorongan Berprestasi & Skor & 72.9 & 71.3 & 71.9 \\
\hline Dorongan Berafiliasi & Skor & 80.1 & 77.1 & 78.2 \\
\hline Dorongan Pengaruh & Skor & 77 & 77.2 & 77.1 \\
\hline Total & Skor & 76.6 & 75.2 & 75.7 \\
\hline
\end{tabular}

Keterangan :

Skor Rendah; 0-59; Sedang; 60-79; Tinggi; 80-100

Terkait dengan dorongan berafiliasi, responden menilai bahwa pengurus DKM mesjid sangat fleksibel dalam menjalin hubungan dengan tokoh agama maupun tokoh masyarakat. Hal mana disebabkan karena sifat mesjid sebagai lembaga yang independen bebas dari sektarian dan harus berada di atas semua aliran maupun golongan. Dorongan pengaruh responden secara umum berada pada kategori sedang cenderung ke tinggi. Responden menilai bahwa terdapat banyak ide yang diberikan dalam berbagai rapat di mesjid selain diyakininya dengan menjabat sebagai pengurus DKM mesjid maka masih diperhitungkan sebagai salah satu tokoh yang diperhitungkan.

Sebagaimana Tabel 2. diketahui bahwa kepemimpinan ketua DKM mesjid berada pada kategori sedang (rataan mencapai 75.6). Dalam hal kepemimpinan ini, 
persepsi ketua DKM mesjid selalu lebih tinggi dari persepsi anggota DKM mesjid. Hal ini lebih disebabkan oleh penilaian terhadap diri pribadi cenderung lebih positif dibandingkan dengan orang lain. Secara umum, skor tertinggi ada pada kemampuan berhubungan dengan orang lain dan skor terendah ada pada kemampuan teknis. Ketua DKM mesjid menilai kemampuan berhubungan dengan orang lain lebih tinggi dari pada kemampuan konseptual dirinya. Hal ini berbeda dengan persepsi anggota DKM mesjid yang menilai bahwa kemampuan berhubungan dengan orang lain dan kemampuan konseptual dari ketua DKM mesjid memiliki nilai yang sama besar.

Penjelasan logis tentang persepsi lebih tinggi ketua DKM mesjid terhadap kemampuan berhubungan dengan orang lain menunjukkan peran power atau pusat interaksi dalam organisasi yang memberinya peran dan kesempatan lebih besar dari pada anggota. Perbedaan persepsi paling terbesar di antara ketua dan anggota DKM mesjid tertuju pada kemampuan berhubungan dengan orang lain. Sebaliknya, antara ketua dan anggota DKM mesjid menunjukkan hampir memiliki persamaan persepsi terhadap subpeubah kemampuan konseptual.

\begin{tabular}{|l|lllll}
\hline Tabel 2. & Rataan kategori responden di Kota Bogor berdasarkan peubah \\
\hline
\end{tabular} kepemimpinan ketua DKM mesjid (Tahun 2015)

\begin{tabular}{|c|c|c|c|c|}
\hline \multirow{2}{*}{$\begin{array}{c}\text { Kepemimpinan ketua DKM } \\
\text { mesjid }\end{array}$} & Pengukuran & \multicolumn{2}{|c|}{ Rataan } & Total \\
\cline { 3 - 5 } & & Ketua DKM & $\begin{array}{c}\text { Anggota } \\
\text { DKM }\end{array}$ & \\
\hline $\begin{array}{c}\text { Kemampuan berhubungan } \\
\text { dengan orang lain }\end{array}$ & Skor & 77.7 & 75.6 & 76.4 \\
\hline Kemampuan teknis & Skor & 72.8 & 71.9 & 72.2 \\
\hline Kemampuan konseptual & Skor & 75.9 & 75.6 & 75.7 \\
\hline Total & Skor & 76.4 & 75.2 & 75.6 \\
\hline
\end{tabular}

Keterangan :

Skor Rendah; 0-59; Sedang; 60-79; Tinggi; 80-100

Secara umum, kemampuan berhubungan dengan orang lain dari ketua DKM mesjid menunjukkan skor tinggi. Sebagai perwakilan representatif dari DKM mesjid, ketua DKM secara formal banyak melakukan berbagai hubungan baik secara internal maupun eksternal, baik dengan individual maupun organisasional. Hal ini disebabkan secara natural bahwa bentuk kepemimpinan merupakan hasil dari semua hubungan yang terjadi di suatu lingkup tertentu. Meskipun demikian, dalam kenyataannya akan sangat sulit memberikan teguran terutama kepada anggota yang lalai melaksanakan tugas, kecuali dengan memberikan perumpamaan sebagai upaya memberikan teguran dari ketua kepada anggota pengurus DKM mesjid. Termasuk dalam mengarahkan anggota lebih kepada peningkatan pelayanan terhadap jamaah seperti penyediaan personil 
sebagai imam shalat, menghubungi penceramah dalam kegiatan perayaan hari besar islam ataupun penyediaan sarana peribadatan, bukannya peningkatan keterampilan melayani jamaah. Dalam hal bimbingan dan pengarahan kerja terhadap bawahan, ketua DKM mesjid melakukannya tidak rutin melainkan hanya sesekali.

Kemampuan teknis ketua DKM mesjid yang terlihat adalah kemampuan dalam mengadakan pertemuan atau rapat untuk membahas masalah yang terjadi di organisasi DKM mesjid meskipun hal tersebut jarang dilakukan bila tidak mau disebut sebagai tidak pernah dilakukan. Kemampuan teknis lainnya dari ketua DKM mesjid seperti melakukan evaluasi secara rutin terhadap pekerjaan anggota pengurus. Dalam hal evaluasi inipun terkesan parsial bukannya global, sehingga tidak bersifat komprehensif dan lintas bidang. Menjadikan evaluasi bisa disebutkan sebagai kegiatan penilaian masalah permukaan bukannya akar masalah.

Dalam hal kemampuan konseptual, ketua DKM mesjid menurut responden telah berusaha menerjemahkan visi dan misi dalam pengelolaan mesjid. Hal tersebut terlihat dari terobosan-terobosan yang dilakukan meskipun banyak tantangan menghadang. Tidak hanya itu, ketua DKM mesjid juga dituntut lebih dapat mengarahkan anggota pengurus lainnya demi kemajuan organisasi DKM mesjid. Setidaknya dapat dilihat dari bagaimana ketua DKM melibatkan pengurus dalam memecahkan masalah-masalah pelik sekaligus secara keorganisasian memberikan legalitas bagi serangkaian tindakan yang mesti diambil.

Tabel 3. $\quad$ Rataan kategori responden di Kota Bogor berdasarkan peubah kompetensi manajerial ketua DKM mesjid (Tahun 2015)

\begin{tabular}{|l|c|c|c|c|}
\hline \multirow{2}{*}{$\begin{array}{l}\text { Kompetensi manajerial } \\
\text { ketua DKM mesjid }\end{array}$} & Pengukuran & \multicolumn{2}{|c|}{ Rataan } & Total \\
\cline { 3 - 5 } & Ketua DKM & $\begin{array}{c}\text { Anggota } \\
\text { DKM }\end{array}$ & \\
\hline $\begin{array}{l}\text { Kompetensi kerjasama } \\
\text { internal }\end{array}$ & Skor & 78.2 & 77.3 & 77.6 \\
\hline $\begin{array}{l}\text { Kompetensi mengelola } \\
\text { organisasi DKM mesjid }\end{array}$ & Skor & 77 & 74.3 & 75.3 \\
\hline $\begin{array}{l}\text { Kompetensi menggalang } \\
\text { kerjasama kelembagaan }\end{array}$ & Skor & 73.5 & 72.4 & 72.8 \\
\hline \multicolumn{1}{c|}{ Total } & Skor & 76.3 & 74.7 & 75.2 \\
\hline
\end{tabular}

Keterangan :

Skor Rendah; 0-59; Sedang; 60-79; Tinggi; 80-100

Kompetensi manajerial ketua DKM mesjid menurut penilaian responden secara umum berada pada kategori sedang (skor mencapai 75.2). Dari seluruh subpeubahnya, kompetensi kerjasama internal dinilai paling tinggi dari semuanya dan subpeubah 
kompetensi menggalang kerjasama kelembagaan dinilai paling rendah (Tabel 3.). Nampaknya responden menilai selama ini ketua DKM mesjid lebih banyak melakukan konsolidasi keorganisasian untuk menjalankan roda organisasi DKM. Orientasi ketua DKM mesjid secara umum masih memdanang pembenahan urusan ke dalam lebih utama bila dibdaningkan dengan urusan ke luar. Dengan demikian salah satu hal yang diprioritaskan ketua DKM mesjid dalam rangka pembenahan internal adalah menciptakan suasana organisasi yang akrab serta menciptakan suasana penuh persahabatan dalam organisasi. Kedua hal itu merupakan bagian dari kompetensi kerjasama internal.

Kompetensi mengelola organisasi DKM mesjid merupakan bagian dari kompetensi manajerial ketua DKM mesjid. Pengurus DKM mesjid merasakan bahwa kemampuan tiap pengurus baik itu terkait dengan pengetahuan, keterampilan, sikap, motivasi, kekosmopolitan, pendidikan, bidang keahlian dan pengalamannya selama ini sangat membantu dalam melaksanakan tugas yang menjadi tanggung jawabnya sebagai pengurus DKM mesjid khususnya dalam mengelola organisasi DKM mesjid.

Sebagai subpeubah dari kompetensi manajerial ketua DKM mesjid, kompetensi menggalang kerjasama kelembagaan dicerminkan dari ketua DKM mesjid yang menjalin komunikasi dengan majelis ta'lim di lingkungan sekitar mesjid. Karakteristik majelis ta'lim yang non formal ditambah dengan daya dukung yang tinggi pada berbagai aktivitas keagamaan menjadikan majelis ta'lim mudah diajak bekerjasama dan menjadi mitra kegiatan yang loyal. Kerjasama kelembagaan secara eksternal yang banyak dilakukan adalah dengan menggalang kerjasama kegiatan dengan para donatur di sekitar wilayah mesjid. Untuk mewujudkan kontribusi penting dari donatur ini difasilitasi oleh tim khusus penggalangan dana yang telah dibentuk sebelumnya sehingga dapat berjalan sebagaimana yang diharapkan.

\section{Analisis pengaruh motivasi pengurus DKM mesjid dan kepemimpinan ketua DKM mesjid terhadap kompetensi manajerial ketua DKM mesjid}

Uji regresi gdana menunjukkan bahwa motivasi pengurus DKM mesjid $\left(\mathrm{X}_{1}\right)$ dan kepemimpinanan ketua DKM mesjid $\left(\mathrm{X}_{2}\right)$ memberikan pengaruh nyata positif terhadap kompetensi manajerial ketua DKM mesjid (Y). Persamaan struktural faktor tersebut dapat dituliskan sebagai berikut:

$Y=0,058 X_{1}+0,058 X_{2}+0,591 €$ 
$\mathrm{R}^{2}=0,409$

Persamaan tersebut menunjukkan bahwa kompetensi manajerial ketua DKM mesjid dipengaruhi secara bersama-sama oleh peubah motivasi pengurus DKM mesjid dengan nilai koefisien 0,058 dan peubah kepemimpinanan ketua DKM mesjid dengan nilai koefisien sebesar 0,058. Hasil penelitian ini memperkuat temuan penelitian yang dilakukan Murfiani dan Jahi (2006), Marius $d k k$ (2007), Nuryanto (2008), dan Anwas (2009) bahwa motivasi berhubungan nyata positif atau berpengaruh nyata positif dengan kompetensi penyuluh pertanian. Temuan serupa Hidayatulloh (2014) menunjukkan bahwa terdapat pengaruh nyata antara motivasi dengan kompetensi penyuluh agama. Demikian juga hubungan kepemimpinan dengan kompetensi yang digambarkan bahwa kepemimpinan seseorang dengan satu set alat (kompetensi) dalam menghadapi berbagai situasi dan kondisi (Bolden et al 2003 : 37). Dalam bidang pendidikan, kepala sekolah berperan dalam meningkatkan kompetensi guru (Nilazarni 2013 : 162; Purwanti $d k k$ 2014 : 396). Secara lengkap hasil analisis regresi pengaruh motivasi pengurus DKM mesjid dan dukungan lingkungan sosial terhadap kompetensi manajerial ketua DKM mesjid dapat dilihat pada Tabel 4.

Terdapat pengaruh nyata positif motivasi pengurus DKM mesjid $\left(\mathrm{X}_{1}\right)$ terhadap kompetensi manajerial ketua DKM mesjid (Y) pada $\alpha$ 0,01. Maknanya, semakin tinggi motivasi pengurus DKM mesjid maka akan menyebabkan kompetensi manajerial ketua DKM mesjid meningkat. Adanya kesenangan dan kebahagiaan atas amanah jabatan yang dirasakan pengurus DKM mesjid ditambah dengan fleksibilitas dalam menjalin hubungan dengan tokoh agama maupun tokoh masyarakat menunjukkan dorongan bekerja termotivasi yang ditunjukkan oleh para pengurus DKM mesjid. Hal ini menjadikan ketua DKM mesjid di satu sisi diuntungkan dan di sisi lain mendapatkan tantangan untuk mengelola semua sumber daya manusia pengurus DKM mesjid. Menjadikan ketua DKM mesjid berusaha untuk menguasai bidang pengelolaan mesjid melalui peningkatan kompetensi manajerialnya. Hal inilah yang menyebabkan terjadinya pengaruh nyata positif motivasi pengurus DKM mesjid terhadap kompetensi manajerial ketua DKM mesjid.

Tabel 4. Hasil Analisis Regresi Kompetensi Manajerial Ketua DKM Mesjid

\begin{tabular}{|c|l|c|c|c|}
\hline No & \multicolumn{1}{|c|}{ Peubah bebas } & Nilai koefisien & t hitung & Nilai $\alpha$ \\
\hline 1 & $\begin{array}{l}\text { Motivasi pengurus DKM mesjid } \\
\left(\mathrm{X}_{1}\right)\end{array}$ & $0,058^{* *}$ & 7,994 & 0,000 \\
\hline 2 & Kepemimpinanan ketua DKM & $0,058^{* *}$ & 5,441 & 0,000 \\
\hline
\end{tabular}


Keterangan :

Analisis statistik dengan $\mathrm{N}=215 ; \alpha=0,05-0,01 ; \mathrm{R}^{2}=0,409$

*) Diperoleh jika $t$ hitung lebih besar dari t tabel dengan nilai signifikan lebih kecil dari $\alpha 0,05$

**) Diperoleh jika t hitung lebih besar dari t tabel dengan nilai signifikan lebih kecil atau sama dengan $\alpha 0,01$

Terdapat pengaruh nyata positif kepemimpinanan ketua DKM mesjid $\left(\mathrm{X}_{2}\right)$ terhadap kompetensi manajerial ketua DKM mesjid (Y) pada $\alpha$ 0,01. Artinya, semakin tinggi kepemimpinanan ketua DKM mesjid ini, akan menyebabkan kompetensi manajerial ketua DKM mesjid ikut meningkat. Kepemimpinan ketua DKM mesjid dapat dilihat dari kemampuan mengadakan pertemuan atau rapat untuk membahas masalah yang terjadi di organisasi DKM mesjid dalam memecahkan masalah-masalah pelik sekaligus secara keorganisasian memberikan legalitas bagi serangkaian tindakan yang mesti diambil. Temuan penelitian menunjukkan bahwa kegiatan rapat ini jarang dilakukan. Meskipun demikian, kemudahan dalam melakukan mobilisasi menunjukkan masih diakuinya kepemimpinan ketua DKM mesjid sebagai koordinator kegiatan pemakmuran mesjid. Sehingga dengan sedikitnyanya kesempatan mengadakan rapat di satu sisi dan mudahnya mobilisasi di sisi lain menjadikan ketua DKM mesjid berusaha untuk meningkatkan kemampuannya mencari cara mendapatkan hasil pemecahan masalah efektif di tengah langkanya kesempatan melakukan pertemuan. Aspek inilah rupanya yang telah menyebabkan terdapatnya pengaruh nyata positif kepemimpinanan ketua DKM mesjid terhadap kompetensi manajerial ketua DKM mesjid.

\section{SIMPULAN}

Berdasarkan pembahasan hasil penelitian, maka dapat disimpulkan beberapa hal sebagai berikut :

1. Motivasi pengurus DKM mesjid berada pada kategori sedang dengan dorongan berafiliasi menempati skor lebih tinggi dibdaningkan dengan subpeubah motivasi lainnya, kepemimpinan ketua DKM mesjid berada pada kategori sedang dengan skor tertinggi ada pada kemampuan berhubungan dengan orang lain dan skor terendah ada pada kemampuan teknis, kompetensi manajerial ketua DKM mesjid menurut penilaian responden secara umum berada pada kategori sedang dengan kompetensi kerjasama internal dinilai paling tinggi.

2. Berdasarkan hasil uji regresi linier bergdana menunjukkan bahwa motivasi pengurus 
DKM mesjid dan kepemimpinanan ketua DKM mesjid memberikan pengaruh nyata positif terhadap kompetensi manajerial ketua DKM mesjid.

\section{DAFTAR PUSTAKA}

Anwas EOM. 2009. Pemanfaatan Media dalam Pengembangan Kompetensi Penyuluh Pertanian : Kasus di Kabupaten Karawang dan Garut Provinsi Jawa Barat. [disertasi]. Bogor : Sekolah Pascasarjana, Institut Pertanian Bogor

Bolden, R., Gosling, J., Marturano, A. dan Dennison, P. 2003. A Review Of Leadership Theory Dan Competency Frameworks. United Kingdom : Centre for Leadership Studies University of Exeter

Buhler P. 2007. Alpha Teach Yourself : Management Skills dalam 24 Jam. Jakarta : Prenada Media Group

Cooper AW dan Graham DL. 2001. "Competencies Needed to be Successful County Agents dan County Supervisors." Journal of Extension February 2001// Volume 39//Number 1//Research in Brief//1RIB3 dalam http://www.joe.org/joe/2001february/rb3.php (Diunduh 11 September 2011).

Culp K., McKee RK., dan Nestor P. 2007 “Identifying Volunteer Core Competencies : Regional Differences." Jurnal of Extension, December 2007 // Volume 45 // Number 6 // Feature Articles // 6FEA3 dalam http://www.joe.org/joe/2007december/a3.php (Diunduh 11 September 2011).

Hidayatulloh, MT. 2014. Strategi Peningkatan Kompetensi Penyuluh Agama Islam di Tiga Daerah Provinsi Jawa Barat. [disertasi]. Bogor : Sekolah Pascasarjana, Institut Pertanian Bogor

Ivancevich J, M, Konopaske dan Matteson. 2008. Perilaku dan Manajemen Organisasi. Jakarta : Erlangga

Karina Purwanti, Murniati A. R. dan Yusrizal. 2014. "Kepemimpinan Kepala Sekolah dalam Meningkatkan Kompetensi Guru Pada SMP Negeri 2 Simeulue Timur" Jurnal Ilmiah DIDAKTIKA Vol. 14, No. 2, Februari 2014, Hal. 390-400

Kasali R. 2008. Mutasi DNA Powerhouse. Jakarta : Gramedia Pustaka Utama

Klausmeier HJ dan Goodwin W. 1971. Learning dan Human Abilities : Educational Psychology. New York : Harper dan Row Publisher

Komaruddin. 1994. Menejemen Berdasarkan Sasaran. Jakarta : Bumi Aksara

Koontz H., O’Donnell C., dan Weihrich H. 1980. Management. New York : McGraw Hill

Kurniawan R dan Jahi A. 2005. "Kompetensi Penyuluh Pertanian di Tujuh Kecamatan di Kabupaten Bekasi, Jawa Barat." Jurnal Penyuluhan, September 2005, Vol. 1, No.1 
Marius JA., Sumardjo., Slamet M., Asngari PS. 2007. "Pengaruh Faktor Internal dan Eksternal Penyuluh terhadap Kompetensi Penyuluh di Nusa Tenggara Timur.“ Jurnal Penyuluhan September 2007, Vol. 3 No. 2

Muliadi D. 2015. Perilaku Organisasi dan Kepemimpinan Pelayanan : Konsep dan Aplikasi Administrasi, Manajemen dan Organisasi Modern. Bandung : Alfabeta

Munir B. 2012. Six Dimension Organization dengan Pendekatan Organization Development. Yogyakarta : Garaha Ilmu

Murfiani F dan Jahi A. 2006. "Kompetensi Penyuluh dalam Pengembangan Modal Agribisnis Kecil, di Kabupaten Bogor, Jawa Barat." Jurnal Penyuluhan Desember 2006, Vol. 2, No. 4 .

Nilazarni. 2013. "Strategi Peningkatan Kompetensi Profesional Guru Oleh Kepada Sekolah Di Madrasah Aliyah Ruhul Islam Anak Bangsa". Jurnal Ilmiah Peuradeun Vol. I, No. 01, September 2013, Hal. 159-172

Nuryanto BG. 2008. Kompetensi Penyuluh dalam Pembangunan Pertanian di Provinsi Jawa Barat. [disertasi]. Bogor : Sekolah Pascasarjana, Institut Pertanian Bogor

Rifa'i AB dan Fahruroji M, 2005. Manajemen Masjid, Mengptimalkan Fungsi Sosial Ekonomi Masjid. Bandung : Benang Merah Press

Reece LB dan Bradant R. 1981. Effective Human Relation in Business. Boston : Haughton Miflin Company

Robin SP. 1996. Orgaizational Culture dan Leadership. New Jersey : Prentice-Hall

Rukmana N. 2009. Manajemen Masjid : Pdanuan Praktis Membangun dan Memakmurkan Masjid. Bandung : MQS Publishing

Rutherford J. 2004. Key Competencies in the New Zealdan Curriculum : A snapshot of consultation. Dalam http://nzcurriculum.tki.org.nz/content/ download/826/5907/file/consult-snapshot.doc (Diunduh 28 September 2011).

Schiffman LG dan Kanuk LL. 1992. Consumer Behavior. New York : Prentice Hall.

Shah JY dan Gardner WL. 2008. Hdanbook of Motivation Science. New York: The Guildford Press

Shihab MQ. 1999. Wawasan Al-Quran: Tafsir Maudhu'i atas Pelbagai Persoalan Umat. Bandung : Mizan

Spencer, LM dan Spencer, SM. 1993. Competence at Work : Model for Superior Performance. New York : John Wiley and Sons. Inc

Stone BB dan Bieber S. 1997. "Competencies : A New Language for Our Work.” Jurnal of Extension, February 1997//Volume 35//Number 1//Commentary//1COM1 dalam http://www.joe.org/joe/1997february/comm1.php (Diunduh 11 September 2011) 
Summers, DCS. 2009. Quality Management : Creating dan Sustaining Organizational Effectiveness. New Jersey : Pearson-Prentice Hall

Sunyoto D. 2013. Teori, Kuesioner dan Proses Analisis Data Perilaku Organisasional. Yogyakarta : CAPS

Suryadi. 2009. Manajemen Mutu Berbasis Sekolah : Konsep dan Aplikasi. Bandung : Sarana Panca Karya Nusa

Terrry GR. 1997. Principles of Management. Illionis : Richard D Irwin

Timpe AD. 1986. Motivation of Personel. New York : KEND Publishing

Uha IN. 2015. Budaya Organisasi, Kepemimpinan dan Kinerja : Proses Terbentuk, Tumbuh Kembang, Dinamika dan Kinerja Organisasi. Jakarta : Prenadamedia Group

Wibowo. 2014. Manajemen Kinerja. Jakarta : Rajawali Pers

Yukl G. 2015. Kepemimpinan dalam Organisasi. Jakarta : Indeks 